\title{
The Information and Data Protection Commissioner's Effectiveness on Transparency
}

\section{Case Study Albania}

The new Albanian law of 2014 "On the Right of Information" fully reformed the existing system regarding the obligation of the public-administration institutions to make available public data to any interested party. Inspired by Western European countries' models like the UK, Sweden, Spain, Germany, etc. it created the Information and Data Protection Commissioner. Considered a special form of external control, the new Institution has the obligation to guarantee the citizens' right to access public data and, at the same time, to have their personal data protected.

The 2014 law makes considerable changes compared with the previous law by liberalizing the citizens' access on public data, making it possible for anyone to request and obtain information considered public, without the need to explain their motives. Notwithstanding, the main novelty is the Information Commissioner, whose main role is to supervise, control and assist the new law implementation. Bearing this in mind, the aim of the paper is to analyze the activity of the Information Commissioner and its decision-making, in order to answer the question whether this new institution will be able to implement the new law and its ambitious objectives. The available data on complaints addressed to the Commissioner, their resolution's modalities and the willingness of the Commissioner to decide when deemed necessary will help in assessing how effective the implementation of the new law and the new institution has been so far, considering that transparency is one of the main pillars of a responsible public administration.

\section{Keywords}

transparency, right of information, public administration, public data. 


\section{Introduction}

Theoretically and practically speaking, transparency as a concept is very difficult to be designated. This is the reason why currently there is no common agreement upon the definition of this concept (Bauhr and Grimes 2012). According to the UN Report, transparency refers to: "unfettered access by the public to timely and reliable information on decisions and performance in the public sector" (Armstrong 2005). According to the law provisions, transparency mainly refers to: "the freedom of access in the administrative documents, the freedom of information, the guarantees of an administrative justice and also the motivation of the taken decisions." ${ }^{1}$ Postcommunist transition countries like Albania have the tendency to restrict the access of the public to official and public information. This is a consequence of the absence of independent public administration during communist regimes. The state structure was centralized, hierarchical and under the complete control of the state party. Transparency is incompatible with the socialist system (Liem 2007). The fall of communism and other totalitarian regimes was in part a moral condemnation of the culture of "secrecy" and lack of access to public documents (Banisar 2006, Bugarič 2012). Based on these premises, Albania, like the other countries of Central and Eastern Europe, faced the challenge of building a public administration based on a new operation system (Armstrong 2005, Relly and Sabharwal 2009).

Transparency in public administration serves various purposes. It ensures legal certainty because decisions become more predictable. By means of transparency, citizens are informed about administrative action and organization, and they are provided with some sort of control: the administration becomes directly accountable towards citizens. Administrative transparency may compensate for a lack of democratic legitimacy and enhance the legitimacy of public administration. ${ }^{2}$ Taking in consideration that the democratic deficit is considered a threat to public administration's legitimacy, the open public-administration theory stresses the importance of individual participation in the adoption of executive regulations and public access to all information on public-administration operations, by obtaining public information on the work of the public administration and participating in adopting its decisions (Bugarič 2012,). Transparency is considered a counterweight to administrative power and may reduce the risk of arbitrary action by the administration. If administrative performance becomes more transparent, it also can be evaluated better (Liem 2007). Transparency is seen as a key factor in helping reduce the corruption in government institutions (Martin 2014, Worthy 2010). Despite the fact that the quality of the record kept by an organization is not necessarily a reflection of the quality of its effectiveness, public-administration transparency increases

1 see http://shtetiweb.org/, a website that aims to promote public information, administered by the Institute for Cooperation and Development (Instituti për Bashkëpunim dhe Zhvillim).

2 SIGMA, OECD, 2014, Report, The principles of Public Administration, Albania. Available at: http://www.sigmaweb.org/publications/Principles-Public-Administration-Nov2014.pdf. 
the effectiveness of public administration and the accountability of the government (James 2006). Toby Mendel's 2008 study of access to information regimes across the world analyzed the "principles occurring frequently" across FOI legislation worldwide. These commonly include transparency, accountability, public participation and informing citizens (Mendel 2008).

Albania's route towards EU integration has raised the necessity for legal and institutional reforms, particularly regarding public-administration authorities. Public-administration transparency and raising the appropriate legal mechanisms to guarantee this transparency has not been the focus of the Albanian's governments at the beginning of its transition processes. This lack of interest caused the existence of restrictions, mostly not legal but practical ones, given that the law provisions for guaranteeing PA's transparency are not sufficient without the establishment of the special security mechanisms. The countries' first important legal measures in this regard were article 23 of the Albanian Constitution and the approval of the law no. 8503 , dated 30 June 1999, "On the right of information on official documents". ${ }^{3}$ This law allowed every interested person to request information contained in official documents. The implementation of the law was entrusted to the People's Advocate, who could issue a recommendation for action contrary to the law. The efficient and effective processing of the public-data requests, when exercising their right to information, depends upon several factors, such as the personnel professionalism, political will, proper administrative structures, good business processes, public information and public trust. The new law adopted in Albania in 2014 has many innovations and improvements which aim to facilitate the transparency of public administration, such as shorter terms, the removal of the legal obligation to prove the reasons why the information is required, unification of practices, liability to publish the public information online, administrative sanctions, etc. In general terms the law has made a radical reform in the right to be informed about public information, making it difficult to analyze all its components in a single article. Despite all the criteria set by the law, enforceability is what sets FOI laws apart from general pledges of access to information made by governments (Holsen 2007). Enforceability is the feature that was lacking in the previous transparency law in Albania, given that the complaints were addressed to the same institution which had refused to give out the information. The OECD in a 2002 report on anti-corruption efforts noted one of the main flaws of the previous law on information in Albania: "there are no adequate mechanisms in place to provide full access to information" (OECD 2002). The 2014 law remedied this lack of an implementation tool by inserting the central supervising authority and the possibility of administrative and court appeal. The literature stresses the benefit of systems with a central authority responsible for implementing the law, as court cases can be rather lengthy. Since the freedom of information law is considered to be one of the main "objective" measures regarding

3 Available at http://www.ijnet.org/img/assets/1033/ALBACC2I-Law-Helen2.doc. 
transparency (Bellver and Kaufmann 2005), the scope of the paper focuses precisely on this new institution the law has created, that of the Commissioner on Information, aiming to ensure the practical implementation of the freedom of information, serving as an administrative appeal and as the administrative body that supervises controls and helps with the implementation of the law.

The Freedom of Information response system is considered to be one of the most important areas which need to be studied in order to be able to examine and understand the implementation of the FOI laws (Holsen 2007). The mission of the Commissioner of the Office of Information is to increase the public understanding regarding their right to access public information and help them during the process. For this reason the law has granted him wide authority, even to impose administrative sanctions to the managers of public institutions. Among others, the focus of the paper is the Information Commissioner, for several reasons:

- The new law has been in force for almost two years, and a considerable part of the required legal criteria is not fulfilled yet, so it is difficult to analyze at the institutional level how the response of the public-administration institutions regarding the information on public data is administered. The majority of publicadministration institutions has appointed a coordinator of the right to information, but has not yet made accessible all the information requests and the way the institution has proceeded in every specific case. When this is done, it will help collect quantitative data, in order to carry out a more complete analysis of the freedom of information in Albania. For these reasons, the activity of the Information Commissioner is a good starting point to analyze the effectiveness of the new law regarding its main goal, making available the public data for everyone interested.

- Furthermore the paper's focus is on the Commissioner's activity, because its mode of operation, mission, objectives, competencies constitute the main novelty of the new law. This institution inspires hopes that the public-administration institutions, unlike the previous law, will successfully implement the new law.

\section{The Albanian legal framework}

A solid legal framework is considered one of the main factors that ensure the adequate implementation and enforcement of the law (Martin 2014). Albanian experience substantiates it. The right to access to public information in Albania is a constitutional right, guaranteed by Article 23 of the Albanian Constitution: "The right to information is guaranteed. 2. Everyone has the right, in compliance with the law, to obtain information about the activity of state organs and of persons who exercise state functions." Being a constitutional right provides it with a special position, but in case the constitutional principles are not complemented with the appropriate 
laws and other normative acts, they may become unenforceable. This occurred with the 1999 Albanian FOI law.

On 18 December 2014, the Albanian Parliament approved law no. 119/2014, "On the right to information". This law abolished law no. 8503, dated 30 June 1999, "On the right to information on official documents". There are substantial changes to the new law, compared with the previous law, aiming at the improvement of the implementation of this right. (Respublica 2014) First of all the new law guarantees public access to all kinds of public information and is not restricted to official documents, as the previous law was. According to the 1999 law, the term "official document" referred to "every kind of document, held by a public authority, in accordance with the applicable rules and that is related to the exercise of a public function." The concept used by the new law is much more ample, defined as the right to access public information. According to the 2014 law, public information regards any kind of data registered in any kind of form and format, during the exercise of public functions, whether prepared by the public authority or not.

The right to information is not restricted by the scope, objective and legal interests of the applicant. The law grants to any person the right to get acquainted with any kind of public information. The law presumes that everyone has a legal interest in specific information which is considered public. This right was acknowledged also by the previous law, but since it lacked the appropriate guaranteeing mechanisms, it was difficult to implement.

If the information is not available in time, it may cause the same damages as not receiving it at all. The time limits for responses by the public authorities who receive a request for information, according to the previous law varied from 40 to 50 days. The new law reduces the time granted to the public authority considerably by obliging it to respond as soon as possible, but not later than 10 working days, from the request's submission. This term may be prolonged only by five days. The failure to handle the request for information within the above-mentioned limits will be considered a refusal.

Transparency is assured in two ways: through the individual requests and through public disclosure of information. With the adoption of the new law on the right to information, all institutions should draft and implement the institutional transparency program in order to guarantee access for citizens and civil society to information. The transparency program will be available without the need for a request. While drafting the transparency program the public authority must take into consideration the public's best interest, especially to make as much information available, in order to decrease the need for individual requests for information. The law defines the information's categories that should be made public without individual request, including laws and bylaws, statutory acts, ethical codes, procedures, forms, addresses, data on public functionaries including their salaries, financial data, public procurement data, etc. 
Individuals who have their RTI requests denied or ignored by public bodies should have the possibility of challenging the decision. Within this framework, as important as having a strong and independent oversight institution is having clear rules regarding the appeal mechanism as well as independent and impartial bodies to evaluate these appeals (Martin 2014). Individuals seeking information should also have an inexpensive option of going to court against the offending institution if necessary (Transparency International 2006). The Albanian law has a two-stage appeal process. The first stage is the Information Commissioner's Office and the second the administrative court.

Pursuant to article 10 of law no. 119/2014 "On the right to information", every public authority will have to nominate a coordinator, to ensure the implementation of the law. The coordinator is one of the institution's civil servants, whose assignment is the coordination of work throughout the institution, or with other public institutions, in order to guarantee the right to information. The Information Commissioner has the right to fine the information coordinators and, in their absence, the executive manager of the public authority. The fines vary from 150,000 to 300,000 ALL (approximately 1,100-2,200 euro). The fines are considerable if one has in mind the average wage in Albania. By giving to the Commissioner the possibility to punish the public-administration officials directly, the law gives significant authority and powers to the Commissioner.

The request for information should be in writing and sent personally, by mail or electronic mail. It should contain the exact identity of the petitioner and his signature. In accordance with the request, the information may be sent by simple mail or through electronic mail. The complainant will decide which the recommended way for receiving the appropriate information is. Public-administration services are free of charge. In case the reproduction of the information costs, than the public authority can charge the applicant with the expenses. This fee is appointed in advance and must be made public through the PA's website and in its public waiting areas. The fee should reflect the real cost of the reproduction of the requested information and the mail cost, when applicable. If the information is requested through electronic mail, it is granted free of charge. Guaranteeing the service at no cost or at a very low cost helps increase the public access to public data.

One of the main innovations of the new law concerns the right to judicial protection, in case the public authority or the Information Commissioner, as the administrative appeal body, should not fulfil their legal obligation. Every individual, legal entity or NGO that considers their legal right to information to be infringed, has the right to submit a complaint to the Information Commissioner. The IC will review the complaint within 30 working days from its refusal or from the term's expiration. The previous law regarding the administrative and judicial complaint provided only general guarantees, without specific provisions. Judicial remedy is 
considered crucial for guaranteeing transparency. ${ }^{4}$ The applicant or the public authority has the right to appeal the Commissioner's decision before the competent administrative court. The competent courts are the administrative courts of first instance. This is an important step ahead compared to the previous law, especially with the inclusion of administrative courts, which have a simplified procedure and shorter terms of judicial processes. Similar experiences in other countries have contributed to constructing an open public administration by improving the access of public information. ${ }^{5}$

\section{The information commissioner's effectiveness}

The new Albanian law on the right to information, drafted with international assistance, is overall considered a good law, which has brought significant progress in guaranteeing this right (Albanian Media Institute 2015). Nevertheless, this does not necessarily mean that Albania now will overcome the practical problems related with the freedom of the public to have liberal access to public information. Transition in Albania has witnessed numerous good laws, which have failed to change the landscape, because of the implementation deficiency. Using legal frameworks to evaluate the access to and availability of information is far from ideal, since countries' levels of implementation of laws vary considerably. Access to information depends, among other things, on well-organized records and a professional civil service (Roberts 2006). This is the reason why the paper aims to achieve its goal of evaluating the effectiveness and applicability of the right to information by using as a criterion the Information Commissioner's activity. The time of entry into force of the law is very short, to enable a full and final analysis. However, a full year of activity of the Information Commissioner allows drawing some general conclusions regarding the effectiveness of this new institution, whose main scope is supervising the public-administration institutions' accomplishment regarding their obligation to grant to the public the information considered public. Analyzing any reform is fraught with methodological difficulties (Worthy 2010). The study is based on the online survey of FOI requests, the annual report of the Information Commissioner Office and analysis of private entities' reports. Referring to the measurement criteria used by advanced information systems in other countries, the main questions that are raised in order to measure the effectiveness and performance of information Commissioners' can be summarized:

1. Do the complaint mechanisms meet the needs of the citizens and the term specified by law?

4 SIGMA, OECD, 2014, Report, The principles of Public Administration. Available at: http://www.sigmaweb.org/publications/Principles-Public-Administration-Nov2014.pdf.

5 The law on public information that was passed in Ireland in 1997 significantly contributed to reforming Ireland's state administration and transforming it into an open public administration (see Bugarič 2012). 
2. How many appeals are made, and what is their percentage compared to the total number of information requests?

3. What percentages of complaints are upheld? ${ }^{6}$

From the procedural perspective, after receiving a complaint from a legal entity, individual or NGO, the Information Commissioner is the competent authority that decides the proceedings to be followed. The first step is the verification of the legal status of the claiming public authority or the subject to whom the request for information was directed. The appointed structure of the office of the Commissioner verifies the facts and the legal base of the complaint. The Commissioner may request the public authority to present in writing its pretensions regarding the case. The law gives the Commissioner the right to investigate not only on the premises of the public authority, but he may also gather information from any other source which he considers necessary. When the Commissioner deems it appropriate he conducts a hearing session. The hearing session is an exceptional case and only held on special occasions, because it is more time-consuming and requires greater engagement of human resources. There have been 2 hearing sessions during 2015. The preferred procedures are the writing session and the administrative inspection performed by the representatives of the office of the Commissioner. The Commissioner staff has performed 107 inspections during 2015. From these data is concluded that the law has given large competences to the Information Commissioner. The proper use of these competences is up to the Commissioner and his staff. The Information Commissioner's influence in many cases is indirect and achieved not by a formal procedure initiated by its institution. Public authorities are more inclined to render public information in case the legal basis of the request is the new law on public information. This is confirmed also by the survey performed by the Respublica center, which attests that in several cases the public authorities act according to the law after receiving the administrative complaint addressed to the Commissioner ${ }^{7}$, but also by the direct request addressed to several public institutions in Albania.

The law on the right of information entered into force in November 2014. The first decisions were taken in 2015. During 2015 the Commissioner made 48 decisions in 274 complaints, and 199 cases were solved through mediation (Table 1). In case the complaint lacks the necessary data to determine which is the documentation requested the Information Commissioner obligates the public author-

6 Office of the Information Commissioner Western Australia. 1998. FOI Standards and Performance Measures. Available at: http://www.humanrightsinitiative.org/programs/ai/ rti/implementation/monitor/foi_performance_measures_wa.pdf; Office of the Information Commissioner of Canada, 2014. Report on Plan and Priorities. 2014-2015. Available at http://www.oic-ci.gc.ca/eng/rpp-2014-2015.aspx

7 Respublica, 2015, Study on the effects of the law 119/2014 "On the right of information" and a comparison with the law 8503/1999, Right of information tested, (E drejta e informimit në bankoprovë), available at: http://www.respublica.org.al/wp-content/uploads/2015/12/Edrejta-e-informimit-ne-bankoprove.pdf, last accessed on 20.07.2016. 
ity to contact the complainant to replenish the missing data. The number of complaints is limited and progressively growing (13 requests/month during 2014, 23 requests/month during 2015). This is understandable taking into consideration the short time of entry into force of the law. The Information Commissioner's Office Report and the Institution's website do not reflect the time spent on every complaint, solved through mediation or with a resolution by the Commissioner, making it impossible to assess the institution performance regarding the legal deadlines.

Table 1

\begin{tabular}{|l|c|}
\hline \multicolumn{2}{|c|}{ Complaints during 2015} \\
\hline Solved through Mediation & $\mathbf{1 9 9}$ \\
\hline Commission Decisions & $\mathbf{4 8}$ \\
\hline Beyond the scope of the law & $\mathbf{1 9}$ \\
\hline Incomplete Complaints & $\mathbf{5}$ \\
\hline Belated Complaints & $\mathbf{3}$ \\
\hline Total & $\mathbf{2 7 4}$ \\
\hline
\end{tabular}

\section{Graphic 1}

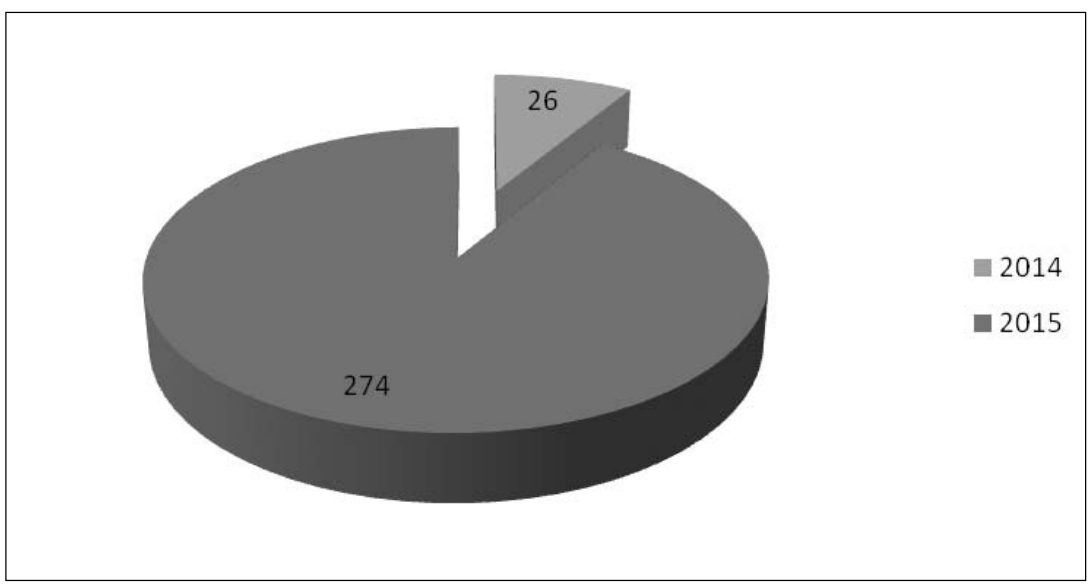

In 2015 there were a total of 274 complaints at the Commissioner office as a result of negative responses or failure to respond to the request. Given that not all public institutions have assigned an information coordinator and created an online database of the information requests, it is impossible to assess the percentage of complaints to the commissioner in relation with the overall number of information requests. (Only 198 public institutions have assigned the information coordinator.) 
The effect that the public complaints to the IC have is another important point of discussion. Reviewing the decisions of the Information Commissioner, several important conclusions can be pointed out. They are fully reasoned, with a detailed overview of the circumstances and effective legal examination. The Commissioner explains all the procedures followed by the complainants and is very clear on the duties he assigns to the public authorities. These properties are encountered in the acceptance and rejection decisions, without any apparent difference. The majority of the requests in 2015 were solved through mediation. The Commissioner made a resolution only in 48 cases by accepting $54 \%$ of the complaints and rejecting $46 \%$. Table 2 recapitulates the reasons for the rejection of the complaints, ranking them according to the frequency encountered. The public authorities and the commissioner can refuse to render information in exemption cases related with private data, or classified information, in accordance with specific laws. Exemptions are the key section of any FOI legislation because their breadth and depth determine how much information is actually disclosed (Holsen 2007). The Commissioner's decisions, provisions and arguments show an overall good understanding of the law and a clear tendency to accord the requested information to the applicant. If this tendency proceeds even after the increase of the number of requests and the passing of the initial enthusiasm about the law, then the system applied in Albania can be considered fully successful.

By reviewing the connection between the legal status of the complainant, if it is a private individual or an NGO, with the accepted or rejected complaints, it is concluded that NGOs have a lower number of rejection decisions. It can be assumed that this is related with a better knowledge of the law on the part of the NGOs and the relatively high percentage of the complaints issued by NGOs, despite not having a direct interest in the information. One of the factors that have influenced this outcome is the conduction of several studies which aim to supervise the law on information. ${ }^{8}$ The reasons of the refusal for both categories of complaints show a better knowledge of the law and its requirements, compared to private individuals. This information emphasizes the need for conducting public-awareness campaigns so that the public becomes fully aware of its legal rights in this area.

8 Albanian Institute for Political Study, 2015, Report. Monitorimi i Transparencës dhe Sjelljes së Administratës Gjyqësore ndaj Publikut [Monitoring of Transparency and Behaviour of the Judicial Administration towards the Public], Tirana. Available at: https://www.osfa.al/sites/ default/files/raporti._rezultatet_e_monitorimit.pdf Respublica, 2015, Study on the effects of the law 119/2014 "On the right of information" and a comparison with the law 8503/1999, Right of information tested, (E drejta e informimit në bankoprovë), available at: http://www.respublica. org.al/wp-content/uploads/2015/12/E-drejta-e-informimit-ne-bankoprove.pdf. 


\section{Graphic 2}

Acceptance or rejection of the requests according to the complainants

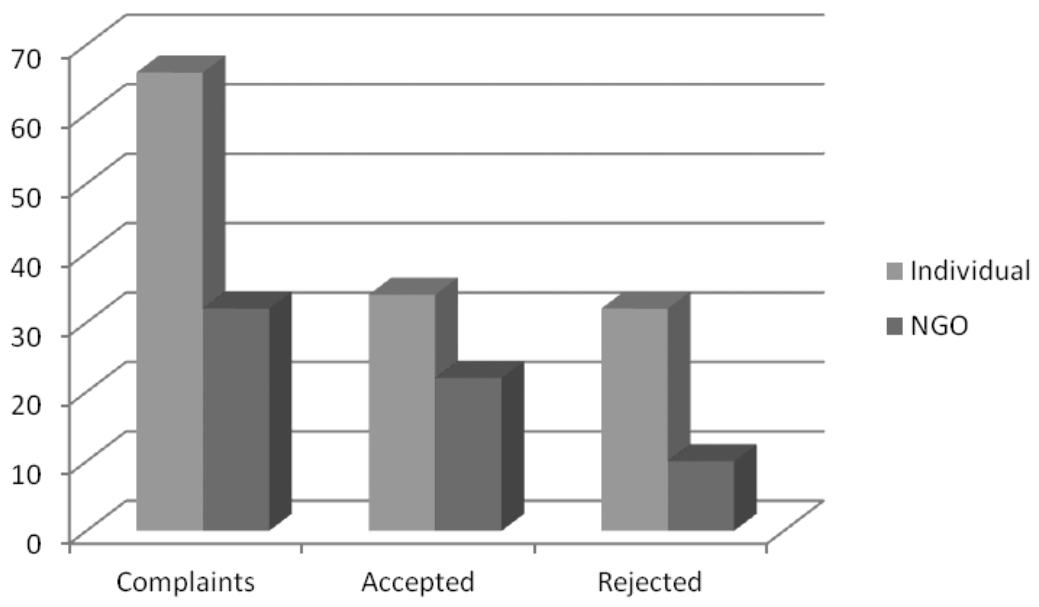

Table 2

Reasons for the rejection of the request by the Commissioner

\begin{tabular}{|l|c|}
\hline \multicolumn{1}{|c|}{ Reason for rejection } & Number of decisions \\
\hline The data requested were personal data. & 7 \\
\hline The public authority already gave a response. & 5 \\
\hline $\begin{array}{l}\text { The subject to whom it was requested was not a public- } \\
\text { administration institution. }\end{array}$ & 3 \\
\hline The legal term had passed. & 2 \\
\hline The information requested did not exist. & 1 \\
\hline The request was not found. & \\
\hline
\end{tabular}

As can be seen from the table the main reason for which the Commissioner has rejected access of the public to a specific set of information is the protection of personal data. According to law no. 9887, dated 10 March 2008, personal data are defined as: "Any information about a physical person, identified or identifiable, directly or indirectly, in particular referred to an identification number or one or more specific factors regarding his physical, physiological, mental, economic, cultural or social identity." The law and the Commissioner recommend interpreting as narrowly as possible the cases when the law restricts the right to access public information. In order to protect the personal data, but also act according to the right of information the Information Commissioner recommends deleting only specific data, in order to preserve the anonymity. 
The public authorities that did not act according to the law and were subjected to the Commissioner's decision were of all kinds, including Universities, Municipalities, Police, Prosecutor, the Offices of the Registry of Immovable Property and even the Informative Services of the State (the secret services in Albania). In the majority of the decisions taken, the Information Commissioner highlights the lack of the appointed coordinator, pointing the breach of a law from public authorities. Despite this the Information Commissioner has not been willing to make penalty decisions. The Commissioner has been cautious in imposing fines. This has happened because the law requests some provisional time in order to give the opportunity to public authorities to comply with the law. One of the decisions ${ }^{9}$ was not initiated by the complaint of an individual or NGO, but as an investigation process, initiated by the Commissioner's office. In this case, the Commissioner concluded that the public authority had failed to implement the law, because the coordinator requested by article 19/4 of the law on information was not appointed. In this case the public-authority administrator was fined.

The applicant or the public authority can appeal the Information Commissioner's decision before the competent administrative court. The Administrative Courts of First Instance have had several cases regarding complaints in order to guarantee the right of information. Firstly, it is very important to emphasize that these decisions could be accessed only through the secretary of the Court. ${ }^{10}$ In breach of the law on the right of information the Administrative Courts in Albania have not installed an electronic system available online. In all of the decisions that were accessible the Court confirms the decision of the Information Commissioner. This happened both in cases of acceptance and rejection. The initiation of investigation processes by the Commissioner without the need of a complaint is another novelty and a good opportunity to help the effectiveness of transparency.

\section{Conclusions}

The Strategy for reforming the public administration in Albania highlights several of the deficiencies that have been estimated in the area of transparency. More specifically mentioned is the significant lack of transparency in the activities and decision-making. Institutions generally provide little information and are not open to transparency. Civil society and interested persons have little access to the activity of

9 Decision of the Commissioner on the Right of Information and the Protection of Personal Data, no. 49, dated 6 November 2015.

10 Accessibility was made more difficult because the Administration of the Administrative Court had to search for the decisions in the paper registers, as the electronic system was not available even for internal use. 
the administration, which tends to be hermetic. ${ }^{11}$ The importance of transparency emerges even in "The national plan for the European integration", adopted by DCM no. 438 and dated 7 February 2014, where the term "transparency" was mentioned in 53 cases.

The first indicator of a healthy FOI regime may be the number of requests, though this may be dependent on who is making the requests and for what information. If the Act is well publicized by government and the media, public awareness of the Act should be high, enabling a high rate of use (Hazell and Worthy 2010). In Albania the statistics about the requests for information to public administration or institutions is not freely accessible, despite the legal duty to display this at the public-administration institution's website. The reason is the lack of implementation of the legal obligation to appoint a coordinator regarding the freedom of information and to register and make public all information requests and their status.

The Information Commissioner's activity is considered crucial for implementing an effective FOI system, because most of the practical deficiencies can be adjusted by him. As outlined in the paper the Information Commissioner is a new institution in Albania, to whom was given the responsibility to supervise the overall implementation of the law on information by the public authorities and the review of special individual cases.

The complaint mechanism is easy and reliable. The Decisions of the Commissioner show a good starting point for the implementation of the new law. The decisions taken by the Commissioner are reasoned and include all legal reasons and legal norms on which they are based. The data show a considerable increase of individual requests towards the Information Commissioner, and this will grant this institution the possibility to have a more active position. The Information Commissioner is a good opportunity to change the approach that the majority of public administration has towards the public disclosure of its activity and documents. The hitherto performance indicates a good start, but there is still much progress to be achieved. Despite the lack of complete data regarding the legal deadlines, the surveys conducted by NGOs and the requests that the author has directly sent to the Commissioner show a tendency to respect the legal deadlines. The increase of the number of requests is obvious and a clear sign of the trust that the Information Commissioner has inspired. Trust is a key element in this process, since the presence or absence of faith motivates individuals to run complaints to the Commissioner or not to. The majority of the complaints are solved through mediation and not through a formal resolution, which is a shorter procedure and in the best interest of the interested party. The Information Commissioner has performed ad-

11 Albanian Ministry of Innovation and Public Administration and the Department of Public Administration, 2015, Crosscutting Public Administration Reform Strategy 2015-2020, Tirana, Available at:

http://dap.gov.al/images/DokumentaStrategjik/PAR_Strategy_2015-2020_English.pdf. 
ministrative inspections in almost half of the complaints submitted, clearly showing his will to fully guarantee the right of information.

The cooperation between the public authorities and the Information Commissioner and the good will to implement the law are the essential requirements for guaranteeing the effectiveness of the legal framework for the right to access to public information. The right to information is included in the crosscutting strategy for the reform in public administration, financed by the European Union. In this strategy the Commissioner's Office has an indicator which measures the total number of the complaints made and the number of sanctions and inspections performed. This indicator will serve as an instrument for monitoring the law on the right of information implementation.

Time will reveal if the Information Commissioner will be able to assume all the rights and privileges given by the law and to exert the duties and competences granted. It is the government duty to publicize the law by aiming to increase the data request as the first step of implementing an effective transparency. The increase in requests will show the real legal status of the Commissioner and its ability to implement the public-information law.

\section{References}

Albanian Media Institute, 2015. Monitorim per Zbatimin e Ligjit për të drejtën e informimit [Monitoring of the Implementation of the law on the right of information]. Tirana, Available at http://www.institutemedia.org/Documents/ PDF/E-DREJTA-INFORMIMIT-2015.pdf (last accessed on 01.07.2016).

Albanian Commissioner on the Right of Information and Protection of Personal Data, 2015, Annual Report, Tirana, available at: https://www.parlament.al/ wp-content/uploads/2016/03/Raporti-Vjetor-2015-KDIMDHP.pdf, last accessed on 15.06.2016.

Albanian Ministry of Innovation and Public Administration and the Department of Public Administration, 2015, Crosscutting Public Administration Reform Strategy 2015-2020, Tirana, Available at: http://dap.gov.al/images/DokumentaStrategjik/PAR_Strategy_2015-2020_English.pdf, (last accessed on 20.10.2016).

Albanian Institute for Political Study, 2015, Report. Monitorimi i Transparencës dhe Sjelljes së Administratës Gjyqësore ndaj Publikut [Monitoring of Transparency and Behaviour of the Judicial Administration towards the Public], Tirana. Available at: https://www.osfa.al/sites/default/files/raporti._rezultatet_e_ monitorimit.pdf, last accessed on: 19.10.2016. 
Armstrong, Elia. 2005. Integrity, Transparency and Accountability in Public Administration: Recent Trends, Regional and International Developments and Emerging Issues. United Nations. Available at http://unpan1.un.org/intradoc/groups/ public/documents/un/unpan020955.pdf (last accessed on 20.10.2016).

Bauhr, Monika and Marcia Grimes. 2012. "What is Government Transparency? New Measures and Relevance for Quality of Government." The Quality Government Institute 2012:16, University of Gothenburg. Available at http:// www.qog.pol.gu.se/digitalAssets/1418/1418047_2012_16_bauhr_grimes. pdf (last accessed on 20.10.2016).

Bellver, Ana and Daniel Kaufmann. 2005. "Transparenting Transparency: Initial Empirics and Policy Applications." World Bank Policy Research Working Paper, Washington, available at: http://siteresources.worldbank.org/INTEAPREGTOPRURDEV/Resources/573691-1175901454225/seminar1_background_reading.pdf, last accessed on: 10.06.2016.

Bugarič, Bojan. 2012. "Openness and Transparency in Public Administration: Challenges for Public Law." Wisconsin International Law Journal 22(3). Available at: http://hosted.law.wisc.edu/wordpress/wilj/files/2012/02/bugaric.pdf (last accessed 10.05.2016).

Decision of the Commissioner on the Right of Information and the Protection of Personal Data, no. 49, dated 6 November 2015, Available at: http://www.idp.al/ images/inspektimi_di/vendim_49_DPD.pdf, (last accessed on 20.10.2016).

Hazell, Robert and Ben Worthy. 2010. "Assessing the Performance of Freedom of Information." Government Information Quarterly 27, 352-359, London. Available at: http://fipa.bc.ca/library/Articles/Assessing_the_performance_ of_Freedom_of_Information--Hazell\%26Worthy_2010.pdf, (last accessed on: 01.05.2016).

Holsen, Sarah. 2007. "Freedom of Information in the U.K., U.S., and Canada." The Information Management Journal. Available at http://www.arma.org/bookstore/files/Holsen.pdf (last accessed: 20. 10. 2016).

James, Simon. 2006. “The Potential Benefits of Freedom of Information." In R. A. Chapman and M. Hunt (eds). Open Government in a Theoretical and Practical Context. Aldershot: Ashgate Publishing, 17-32.

Law no. 119/2014. "On the Right to Information."

Law no. 9887, dated 10 March 2008. "For the Protection of Personal Data." 
Liem, Susan I. 2007. Constituents of Transparency in Public Administration with Reference to Empirical Findings from Estonia. Dissertation of the University of St. Gallen, Graduate School of Business Administration, Economics, Law and Social Sciences (HSG), Gutenberg, Schaan. Available at http://www1.unisg. ch/www/edis.nsf/SysLkpByIdentifier/3350/\$FILE/dis3350.pdf (last accessed on 15.07.2016).

Martin, Maíra. 2014. "Right to Information Laws: Impact and Implementation." Transparency International, Anti-Corruption Resource Center 2014:10. Available at http://www.u4.no/publications/right-to-information-laws-impactand-implementation/downloadasset/3578 (last accessed on 02.07.2016).

Mendel, Toby. 2008. Freedom of Information: A Comparative Legal Survey. $2^{\text {nd }}$ edn. Paris: UNESCO. Available at http://portal.unesco.org/ci/en/ files/26159/12054862803freedom_information_en.pdf/freedom_information_en.pdf(last accessed 10.07.2016).

OECD. 2002. Anti-Corruption Measures in South Eastern Europe: Civil Society's Involvement. Available at http://www1.oecd.org/daf/SPAIcom/pdf/CSreport. pdf (last accessed 01.07.2016).

Office of the Information Commissioner Western Australia. 1998. FOI Standards and Performance Measures. Available at: http://www.humanrightsinitiative. org/programs/ai/rti/implementation/monitor/foi_performance_measures_ wa.pdf (last accessed 19.10.2016).

Office of the Information Commissioner of Canada, 2014. Report on Plan and Priorities. 2014-2015. Available at http://www.oic-ci.gc.ca/eng/rpp-2014-2015.aspx (last accessed 17.07.2016).

Privacy International, David Banisar, 2006, Survey Report, "Freedom of Information around the World. A Global Survey to Access to Government Information Laws", available at:

http://www.freedominfo.org/documents/global_survey2006.pdf (last accessed on 15.07.2016).

Relly, Jeannine and Meghna Sabharwal. 2009. "Perceptions of Transparency of Government Policymaking: A Cross-National Study." Government Information Quarterly 26(1), 148-157., available at: file:///C:/Users/Admin/Downloads/ Relly_Sabharwal\%202009.pdf, (last accessed on 20.10.2016).

SIGMA, OECD, 2014, Report, The principles of Public Administration, Albania, Available at: http://www.sigmaweb.org/bylanguage/albanian/PrinciplesPublic-Administration-Alb.pdf, last accessed on: 20.10.2016. 
Respublica, 2014, Komentar i ligjit nr. 119/ 2014 "Për të drejtën e informimit" [Commentary of the law no. 119/2014 "On the right to information"]. Available at https://issuu.com/respublicalb/docs/komentar_foi_web (last accessed on 15.05.2016).

Roberts, Alasdair. 2006. Blacked out: Government Secrecy in the Information Age. New York: Cambridge University Press, pg.112.

Respublica, 2015, Study on the effects of the law 119/2014 "On the right of information" and a comparison with the law 8503/1999, Right of information tested, (E drejta e informimit në bankoprovë), available at: http://www.respublica. org.al/wp-content/uploads/2015/12/E-drejta-e-informimit-ne-bankoprove. pdf, last accessed on 20.07.2016.

Transparency International. 2006. "Using the Right to Information as an AntiCorruption Tool." Available at http://oas.org/dil/access_to_information_human_Policy_Recommendations_Transparency_International_Right_to_Information_as_an_Anti-Corruption_Tool.pdf (last accessed on 30.07.2016).

Worthy, Ben. 2010. "More Open but Not More Trusted? The Effect of the Freedom of Information Act 2000 on the United Kingdom Central Government." Governance: An International Journal of Policy, Administration, and Institutions 23(4), 561-582. 